\title{
PENGARUH KOMPENSASI DAN DISIPLIN KERJA TERHADAP KINERJA KARYAWAN PT. PEDAGANG UNGGUL INDONESIA (X-SELL)
}

\author{
Mohammad Komarudin ${ }^{1)}$ \\ 1) Mahasiswa Program Studi Manajemen FE UNKRIS \\ Nuridin ${ }^{2)}$ \\ 2) Dosen Program Studi Manajemen FE UNKRIS \\ Alamat: Kampus UNKRIS, Jatiwaringin Jakarta Timur \\ Email: h.nuridin58@gmail.com
}

\begin{abstract}
Analyze the effect of compensation and work discipline on the performance of the employees of PT. Indonesian Superior Trader (X-Sell). The research method uses qualitative and quantitative descriptive analysis, the analysis model used is linear regression both partially or simultaneous. The study population of all employees of PT. Indonesian Superior Traders (X-Sell) totaling 30 employees. The sampling technique of this study uses saturated sampling, which is the technique of determining the sample if all members of the population are used as samples. Result Compensation and work discipline have a positive and significant effect on the performance of employees of Indonesian Superior Traders (X-Sell) partially or simultaneous.
\end{abstract}

Keywords: Compensation, work discipline and employee performance

\section{PENDAHULUAN}

Suatu perusahaan, baik swasta nasional maupun swasta asing berusaha untuk bersaing dengan perusahaanperusahaan yang sudah berdiri sebelumnya. Mereka berlomba-lomba untuk memberikan layanan yang terbaik bagi masyarakat dan berusaha mendapatkan kepercayaan masyarakat agar bisa bertahan di dunia persaingan bisnis. Agar bisa bersaing dengan perusahaan lainnya di dunia bisnis global, maka perusahan dituntut untuk memiliki kelebihan-kelebihan tertentu yang tidak dipunyai oleh perusahaan lainnya. Pelayanan konsumen yang optimal dan berkualitas "PRIMA". Pelayanan konsumen yang optimal dan prima sudah tentu menempatkan konsumen sebagai pusat aktifitas bisnis perusahaan. Perusahaan harus benar-benar menempatkan konsumen sebagai raja yang harus dilayani, dipenuhi kebutuhannya, dipuaskan perasaannya, dan tidak dikecewakan. Apabila produk perusahaan memiliki masa garansi 1 tahun atau 2 tahun, hendaknya masa garansi itu benar-benar diwujudkan dan komitmen dalam memenuhi garansi yang bersangkutan.

Sebagaimana tertuang dalam dunia bisnis yang sudah mengglobal bahwa konsumen yang puas maka ia akan memberitahukan pada orang lain akan kepuasan yang diraih sampai dengan 6 orang. Namun apabila ia tidak puas, maka ia akan menceritakan sampai dengan 2 lusin orang untuk mengungkapkan kekecewaannya. Betapa banyak orang yang kecewa pada saat membeli produk atau jasa, kemudian 
mengadukannya ke perusahaan penjual, namun ternyata tidak direspon positif oleh perusahaan yang bersangkutan dan bahkan justru sembunyi tangan dengan berbagai alasan. Hal ini sudah jelas akan mengecewakan konsumen. Perusahaan yang menempatkan konsumen sebagai pusat aktifitas bisnis, maka akan senantiasa mendengarkan saran dan masukan konsumen demi perbaikan kegiatan bisnis perusahaan agar lebih baik lagi. Dengarkanlah konsumen, dan jangan dibantah dulu. Bisa jadi masukan dan saran konsumen tersebut benar dan bisa dirasakan perusahaan untuk masa yang akan datang. Perusahaan besar dalam menghasilkan produk atau jasa tentunya berdasarkan kebutuhan dan keinginan konsumen, dengan kata lain perusahaan tidak boleh menciptakan produk atau jasa seenaknya dan sesuai keinginan sendiri tanpa melihat apa yang dibutuhkan dan diinginkan konsumen.

Namun karena beragamnya karakteristik konsumen, maka produk atau jasa yang ada tentunya memiliki segmen pasar tersendiri yang berbeda antara kelas konsumen yang satu dengan yang lain. Dengan kata lain, perusahaan memiliki variasi produk atau jasa untuk berbagai jenis konsumen dalam membelinya. Perusahaan yang mampu menerapkan strategi pasar tentunya akan meraih pangsa pasar yang luas dan keuntungan yang besar karena berhasil dalam menjangkau semua kelas konsumen.

Sumber daya manusia adalah faktor produksi yang sangat dibutuhkan dalam menunjang kelangsungan hidupnya suatu perusahaan, ini berarti bahwa sumber daya manusia tersebut dituntut memiliki skill yang optimal atau kemampuan yang tinggi, karena itulah manusia tidak patut disamakan dengan faktor produksi lainnya. Persaingan antar perusahaan maupun antar negara berlangsung secara bebas dan ketat karena banyak bermunculan perusahaan asing di dalam negeri yang disebabkan oleh semakin tipisnya batas antar negara. Kondisi seperti ini menyebabkan perusahaan harus mampu meningkatkan kualitas perusahaan. Kinerja suatu perusahaan bisa dilihat dari aspek Sumber Daya Manusia, Pemasaran, Operasi dan Keuangan. Dalam penelitian ini kinerja perusahaan dibatasi hanya untuk meneliti kinerja Sumber Daya Manusia. Pihak manajemen dituntut untuk mampu meningkatkan kemampuan dan profesionalismenya, agar manajemen perusahaan mampu mencapai tujuantujuan perusahaan yang telah ditetapkan sebelumnya. Penulis melakukan penelitian pada PT. Pedagang Unggul Indonesia (X-Sell), perusahaan yang bergerak dibidang jasa pemasaran atau direct selling, penulis ingin mengetahui kondisi kinerja karyawan pada perusahaan tersebut ditengah perkembangan dan meningkatnya persaingan dalam dunia usaha.

Kinerja karyawan merupakan tingkat pencapaian atau hasil kerja seseorang dari sasaran yang harus dicapai atau tugas yang harus dilaksanakan sesuai dengan tanggung jawab masing-masing dalam kurun waktu tertentu. Untuk mencapai tujuan perusahaan, diperlukan pengelolaan sumber daya manusia seefektif dan seefisien mungkin. Manajemen sumber daya manusia tidak hanya memperhatikan kepentingan perusahaan akan tetapi juga harus memperhatikan kebutuhan karyawan dan tuntutan masyarakat luas menuju tercapainya efektivitas, efisiensi, produktivitas kinerja perusahaan. PT. Pedagang Unggul Indonesia (X-Sell) adalah perusahaan yang bergerak dibidang jasa pemasaran atau direct selling, dituntut untuk memiliki karyawan yang berkualitas, kreatif dan inovatif agar mampu menghadapi tantangan di dunia bisnis, hal ini karena tugas pelayanan 
yang diberikan oleh sangat kompleks. Tentutnya setiap karyawan dituntut untuk dapat bekerja sesuai tugas pokok dan fungsinya dengan baik sehingga mampu menghadapi munculnya pesaing-pesaing di bidang yang sama yang lebih efektif dan efisien dalam bekerja mencapai tujuan.

Kemajuan suatu perusahaan sangat dipengaruhi oleh kualitas sumber daya manusia khususnya kinerja. Kinerja pada dasarnya adalah suatu yang dilakukan atau tidak dilakukan karyawan sehingga seberapa banyak mereka memberikan konstribusi kepada organisasi atau perusahan, termasuk hasil pelayanan yang diberikan kepada masyarakat. Kinerja karyawan yang optimal adalah gambaran dari sumber daya manusia yang berkualitas. Kinerja menurut Umam (2010) adalah "hasil kerja yang dicapai oleh individu sesuai dengan peran atau tugasnya dalam periode tertentu, yang dihubungkan dengan ukuran nilai atau standar tertentu dari organisasi tempat individu tersebut bekerja". Untuk dapat meningkatkan kinerja karyawan dapat melalui pemberian kompensasi dan peningkatan disiplin kerja bagi seluruh karyawannya. Kompensasi adalah semua imbalan yang diterima oleh seorang pekerja atas jasa atau hasil kerjanya pada sebuah organisasi/perusahaan dimana imbalan tersebut dapat berupa uang ataupun barang, baik langsung ataupun tidak langsung. Kompensasi merupakan suatu penghargaan yang diberikan oleh pihak pemimpin perusahaan kepada karyawan agar mereka bekerja dengan motivasi tinggi dan berprestasi dalam mencapai tujuan-tujuan organisasi.

Kompensasi dapat diartikan sebagai bentuk pembayaran langsung yang didasarkan atau dikaitkan langsung dengan kinerja karyawan, meningkatnya kinerja karyawan secara keseluruhan pada suatu perusahaan akan meningkatkan pula kelancaran proses kerja dan dengan kelancaran proses kerja akan mempermudah tercapainya tujuan dari yang bersangkutan. Menurut Sedarmayanti (2017), kompensasi adalah "segala sesuatu yang di terima oleh karyawan sebagai balas jasa kerja mereka".

Faktor yang dapat mempengaruh kinerja karyawan adalah tingkat disiplin kerja. Disiplin kerja sangat diperlukan dalam rangka meningkatkan kinerja perusahaan. Disiplin kerja disini berarti sifat ketaatan dan kepatuhan pada aturan yang berlaku yang di tetapkan oleh perusahaan. Adapun pendapat yang dikemukakan oleh Hasibuan (2013) menyatakan bahwa "semakin baik disiplin kerja seorang karyawan, maka semakin tinggi hasil kinerja yang akan dicapai”. Kurangnya disiplin kerja akan berpengaruh terhadap efisiensi dan efektivitas tugas pekerjaan. Jika disiplin kerja dalam suatu perusahaan tidak di tegakkan maka kemungkinan tujuan yang ditetapkan tidak dapat dicapai secara efektif dan efisien.

Tujuan penelitian ini adalah untuk mengetahui "Pengaruh kompensasi dan disiplin kerja terhadap kinerja karyawan PT. Pedagang Unggul Indonesia (XSell)".

\section{LANDASAN TEORI}

\section{Kompensasi}

Pemberian kompensasi yang tepat akan berpengaruh positif terhadap karyawan, karena tidak dapat dipungkiri bahwa kompensasi menjadi tujuan utama untuk sebagian besar karyawan yang bekerja di dalam suatu perusahaan.

$$
\text { Menurut Dessler (2011), }
$$

Kompensasi karyawan adalah "semua bentuk pembayaran atau hadiah yang diberikan kepada karyawan dan muncul dari pekerjaan mereka", Sedangkan menurut Hasibuan (2013), Kompenasi adalah "semua pendapatan yang 
berbentuk uang, barang langsung atau tidak langsung yang diterima karyawn sebagai imbalan atas jasa yang diberikan kepada perusahaan".

Berdasarkan beberapa definisi di atas, penulis menyimpulkan bahwa kompensasi adalah segala sesuatu yang diberikan perusahaan kepada karyawan, sebagai balas jasa atau imbalan atas kinerja yang dihasilkan oleh karyawan, untuk kepentingan perusahaan. Kompensasi bisa berbentuk uang ataupun fasilitasn yang diberikan perusahaan pada karyawan.

Menurut Hasibuan, (2013) Faktorfaktor yang mempengaruhi besarnya kompensasi, antara lain sebagai berikut: 1). "Penawaran dan permintaan tenaga kerja; Jika pencari kerja (penawaran) lebih banyak daripada lowongan pekerjaan (permintaan) maka kompensasi relatif kecil. Sebaliknya, jika pencari kerja sedikit daripada lowongan pekerjaan, maka kompensasi relatif besar. 2). Kemampuan dan kesediaan perusahaan; Apabila kemampuan dan kesediaan perusahaan untuk membayar semakin baik maka tingkat kompensasi akan semakin besar. Tetapi sebaliknya, jika kemampuan dan kesediaan perusahaan untuk membayar kurang maka tingkat kompensasi relatif kecil. 3). Serikat buruh/Organisasi karyawan; Apabila serikat buruhnya kuat dan berpengaruh maka tingkat kompensasi semakin besar. Sebaliknya jika serikat buruh tidak kuat dan kurang berpengaruh maka tingkat kompensasinya kecil. 4). Pemerintah dengan undang-undang Keppres; Pemerintah dengan Keppres menetapkan besarnya batas upah/balas jasa minimum. Peraturan pemerintah ini sangat penting supaya pengusaha tidak sewenang-wenang menetapkan besarnya balas jasa bagi karyawan. Pemerintah berkewajiban melindungi masyarakat dari tindakan sewenang-wenang. 5). Biaya hidup; Apabila hidup didaerah itu tinggi maka tingkat kompensasi/upah semakin besar. Sebaliknya, jika tingkat biaya hidup didaerah itu rendah maka tingkat kompensasi/relatif kecil. 6). Posisi jabatan karyawan; Karyawan yang menduduki jabatan yang lebih tinggi maka tingkat kompensasi/upah semakin besar. Sebaliknya karyawan yang menduduki jabatan yang lebih rendah akan memperoleh gaji/kompensasi yang kecil. 7). Pendidikan dan pengalaman kerja; Jika pendidikan lebih tinggi dan pengalaman kerja lebih lama maka gaji/balas jasa akan semakin besar, karena kecakapan serta keterampilannya lebih baik. Sebaliknya, karyawan yang berpendidikan rendah dan pengalam kerja yang kurang maka tingkat gaji/ kompensasinya kecil. 8). Kondisi perekonomian nasional; Apabila kondisi perekonomian nasional sedang maju maka tingkat upah/kompensasi akan semakin besar, karena akan mendekati kondisi. Sebaliknya, jika kondisi perekonomian kurang maju (depresi) maka tingkat upah rendah, karena terdapat banyak pengangguran. 9). Jenis dan sifat pekerjaan; Kalau jenis dan sifat pekerjaan sulit mempunyai risiko (finansial, keselamatan) yang besar maka tingkat upah/balas jasanya semakin besar karena membutuhkan kecakapan serta ketelitian untuk mengerjakannya. Tetapi jika jenis dan sifat pekerjaannya mudah dan resiko (finansial, kecelakaan) kecil, tingkat upah/balas jasanya relatif rendah".

Kompensasi yang diberikan perusahaan pada karyawan bisa digolongkan menjadi beberpa jenis. Sofyandi (2008). Mengemukakan kompensasi pada umumnya bisa dibedakan menjadi dua jenis, yaitu: 1). "Kompensasi Langsung; Kompensasi langsung adalah kompensasi yang diberikan kepada karyawan sebagai imbalan atas pekerjaan yang dia lakukan untuk perusahaan. Contohnya: gaji, 
insentif, bonus, tunjangan jabatan. 2). Kompensasi Tidak Langsung; Kompensasi tidak langsung adalah pemberian kompensasi kepada karyawan sebagai upaya perusahaan untuk meningkatkan kesejahteraan karyawan. tentunya pemberian kompensasi ini tidak berkaitan langsung dengan pekerjaan yang dilakukan oleh karywan tersebut. Contohnya: tunjangan, fasilitas dan pelayanan yang diberikan perusahaan".

Indikator dalam pemberian kompensasi untuk karyawan tentu berbeda-beda. Hasibuan (2013), mengemukakan secara umum indikator kompensasi, yaitu. 1). "Gaji merupakan uang yang diberikan setiap bulan kepada karyawan sebagai balas jasa atas kontribusinya. 2). Upah merupakan imbalan yang diberikan secara langsung kepada karyawan yang didasarkan pada jam kerja. 3). Insentif merupakan imbalan finansial yang diberikan secara langsung kepada karyawan yang kinerjanya melebihi standar yang ditentukan. 4). Tunjangan merupakan kompensasi yang diberikan kepada karyawan tertentu sebagai imbalan atas pengorbanannya. 5). Fasilitas merupakan sarana penunjang yang diberikan oleh organisasi”.

\section{Disiplin Kerja}

Disiplin kerja adalah suatu sikap dan tingkah laku yang menunjukkan ketaatan karyawan terhadap peraturan perusahaan yang sudah diteatapkan.

Menurut Sutrisno, (2011). Disiplin kerja karyawan adalah "perilaku seseorang yang sesuai dengan peraturan, prosedur kerja yang ada atau disiplin adalah sikap, tingkah laku dan perbuatan yang sesuai dengan peraturan dari organisasi baik tertulis maupun yang tidak tertulis". Sedangkan menurut Moekijat (2011) tujuan utama dari disiplin adalah "untuk mendorong karyawan berprilaku sepantasnya ditempat kerja, dimana prilaku yang sepantasnya ditetapkan sebagai kepatuhan terhadap peraturan dan prosedur berfungsi sama dengan peraturan undang-undang masyarakat". Selanjutnya menurut Rivai, (2010), disiplin kerja adalah "suatu alat yang digunakan para manajer untuk berkomunikasi dengan karyawan agar mereka bersedia untuk mengubah suatu perilaku serta sebagai suatu upaya untuk meningkatkan kesadaran dan kesediaan seseorang untuk mentaati semua peraturan perusahaan dan norma-norma sosial yang berlaku".

Menegakkan suatu kedisiplinan penting bagi perusahaan, sebab kedisiplinan berisikan peraturanperaturan yang harus ditaati karyawan. Dengan kedisiplinan diharapkan dapat membuat pekerjaan seefisien mungkin. Disiplin kerja dapat dilihat sebagai sesuatu yang besar manfaatnya, baik bagi kepentingan organisasi maupun bagi para karyawan. Bagi organisasi adanya disiplin kerja akan menjamin terpeliharanya tata tertib dan kelancaran pelaksanaan tugas, sehingga diperoleh hasil yang optimal. Sedangkan bagi karyawan akan diperoleh suasana kerja yang menyenangkan sehingga akan menambah semangat kerja dalam melaksanakan pekerjaannya.

Menurut Saydam (2011). Manfaat dari penerapan disiplin kerja yang akan terlihat pada: 1). "Tingginya rasa kepedulian karyawan terhadap pencapaian tujuan perusahaan. 2). Tingginya semangat dan gairah kerja para karyawan dalam melakukan pekerjaannya. 3). Berkembangnya rasa memiliki dan kesetiakawanan yang tinggi di kalangan karyawan. 4). Besarnya tanggung jawab para karyawan melaksanakan tugas dengan sebaikbaiknya. 5). Meningkatnya efisiensi dan produktivitas para karyawan".

Pada dasarnya banyak indikator yang mempengaruhi tingkat kedisiplinan 
karyawan suatu perusahaan, diantaranya yang disampaikan oleh Moenir (2014). Indikator - indikator yang mempengaruhi disiplin kerja: 1). "Ketepatan Waktu; Ketepatan waktu dalam pekerjaan dan tugas, meliputi: a). Ketepatan waktu dalam melaksanakan tugas. b). Penghematan waktu dalam melaksanakan tugas. 2). Tanggung Jawab; Tanggungjawab dalam pekerjaan dan tugas, meliputi: a). Melakukan pekerjaan sesuai dengan rencana. b). Mengevaluasi hasil pekerjaan. c). Keberanian menerima resiko kesalahan. 3). Ketaatan; Ketaatan terhadap peraturan yang telah ditetapkan, meliputi: a). Ketaatan terhadap jam kerja. b). Ketaatan terhadap pimpinan. c). Ketaatan terhadap prosedur dan metode kerja".

\section{Kinerja}

Kinerja ialah tingkat keberhasilan seseorang secara keseluruhan selama kurun waktu tertentu di dalam menjalankan tugas dibandingkan dengan berbagai kemungkinan, seperti standar hasil kerja, target atau sasaran atau kriteria yang telah ditentukan terlebih dahulu dan telah disepakati bersama. Performance atau kinerja merupakan "hasil atau keluaran dari suatu proses" (Nurlaila, 2010). Menurut pendekatan perilaku dalam manajemen, kinerja adalah "kuantitas atau kualitas sesuatu yang dihasilkan atau jasa yang diberikan oleh seseorang yang melakukan pekerjaan". (Luthans, 2012).

Kinerja merupakan prestasi kerja, yaitu "perbandingan antara hasil kerja dengan standar yang ditetapkan". (Dessler, 2011). Kinerja adalah "hasil kerja baik secara kualitas maupun kuantitas yang dicapai oleh seseorang dalam melaksanakan tugas sesuai tanggung jawab yang diberikan". (Mangkunagara, 2017).
Faktor yang mempengaruhi kinerja menurut Kasmir (2016), menguraikannya sebagai berikut: 1). "Kemampuan dan keahlian; Merupakan kemampuan atau skill yang dimiliki seseorang dalam melakukan suatu pekerjaan. Semakin memiliki kemampuan dan keahlian maka akan dapat menyelesaikakn pekerjaannya secara benar, sesuai dengan yang telah ditetapkan. Artinya karyawan yang memiliki kemampuan dan keahlian yang lebih baik, maka akan memberikan kinerja yang baik pula demikian sebaliknya. Dengan demikian kemampuan dan keahlian akan mempengaruhi kinerja seseorang. 2). Pengetahuan; Maksudnya adalah pengetahuan tentang pekerjaan. Seseorang yang memiliki pengetahuan tentang pekerjaan secara baik akan memberikan hasil pekerjaan yang baik, demikian sebaliknya. Jadi dapat disimpulkan bahwa pengetahuan tentang pekerjaan akan mempengaruhi kinerja. 3). Rancangan kerja; Merupakan rancangan pekerjaan yang akan memudahkan dalam mencapai tujuannya. Artinya jika suatu pekerjaan memiliki rancangan yang baik, maka akan memudahkan untuk menjalankan pekerjaan tersebut secara teapt dan benar. Demikian pula sebaliknya, maka dapat disimpulkan bahwa rancangan pekerjaan akan mempengaruhi kinerja seseorang. 4). Kepribadian; Yaitu kepribadian seseorang atau karakter yang dimiliki seseorang. Setiap orang memiliki kepribadian atau karakter yang berbeda satu dengan yang lainnya. Seseorang yang memiliki kepribadian atau karakter yang baik akan dapat melakukan pekerjaan secara sungguh-sungguh penuh tanggung jawab sehingga hasil pekerjaan juga baik. 5). Motivasi kerja; Motivasi kerja merupakan dorongan bagi seseorang untuk melakukan pekerjaan. Jika karyawan memiliki dorongan yang kuat dari dalam dirinya atau dorongan 
dari luar dirinya (misalnya dari pihak perusahaan), maka karyawan akan terangsang atau terdorong untuk melakukan pekerjaan dengan bai. Pada akhirnya dorongan atau rangsangan baik dari dalam maupun dari luar diri seseorang akan mengahasilkan kinerja yang baik. 6). Kepemimpinan; Kepemimpinan merupakan perilaku seorang pemimpin dalam mengatur, mengelola dan memerintah bawahannya untuk mengerjakan suatu tugas dan tanggung jawab yang diberikannya. 7). Gaya kepemimpinan; Merupakan gaya atau sikap seorang pemimpin dalam menghadapi atau memerintah bawahannya. 8). Budaya organisasi; Merupakan kebiasaan-kebiasaan atau norma-norma yan berlaku dan dimiliki oleh suatu organisasi atau perusahaan. Kebiasaan-kebiasaan atau norma-norma ini mengatur hal-hal yang berlaku dan diterima secara umum serta harus dipatuhi oleh segenap anggota suatu perusahaan atau organisasi. 9). Kepuasan kerja; Merupakan perasaan senang atau gembira, atau perasaan suka seseorang sebelum dan setelah melakukan suatu pekerjaan. Jika karyawan merasa senang atau gembira atau suka untuk bekerja, maka hasil pekerjaan akan baik pula. 10). Lingkungan kerja; Merupakan suasana atau kondisi disekitar lokasi tempat bekerja. Lingkungan kerja dapat berupa rungan, layout, sarana dan prasarana serta hubungan kerja dengan sesama rekan kerja. 11). Loyalitas; Merupakan kesetiaan karyawan untuk tetap bekerja dan membela perusahaan di mana tempatnya bejerha. Kesetiaan ini ditunjukan dengan terus bekerja sungguhsungguh sekalipun perusahaannya dalam kondisi kurang baik. 12). Komitmen; Merupakan kepatuhan karyawan untuk menjalankan kebijakan atau peraturan perusahaan dalam bekerja. Komitmen juga dapat diartikan kepatuhan karyawan kepada janji-janji yang telah dibuatnya.
Atau dengan kata lain komitmen merupakan kepatuhan untuk menjalankan keputusan yang telah dibuat. 13). Disiplin kerja; Merupakan usaha karyawan untuk menjalankan aktivitas kerjanya secara sungguh-sungguh. Disiplin kerja dalam hal ini dapat berupa waktu, misalnya masuk kerja selalu tepat waktu. Kemudian disiplin dalam mengerjakan apa yang diperintahkan kepadanya sesuai dengan perintah yang harus dikerjakan. Karyawan yang disiplin akan mempengaruhi kinerja”.

Ada dua syarat utama yang diperlukan guna melakukan penilaian kinerja yang efektif, yaitu 1) "adanya kriteria kinerja yang dapat diukur secara objektif; dan 2) adanya objektivitas dalam proses evaluasi". (Gomes, 2003).

Dengan demikian, dalam melalukan penilaian atas prestasi kerja para pegawai harus terdapat interaksi positif dan kontinu antara para pejabat pimpinan dan bagian kepegawaian. Penilaian kinerja, Setiap perusahaan atau organisasi harus dapat menyediakan suatu sarana untuk menilai kinerja karyawan dan hasil penilaian dapat dipergunakan sebagai informasi pengambilan keputusan manajemen tentang kenaikan gaji/upah, penguasaan lebih lanjut, peningkatan kesejahteraan karyawan dan berbagai hal penting lainnya yang dapat mempengaruhi karyawan dalam melaksanakan pekerjaannya.

Penilaian kinerja sangat berguna untuk menentukan kebutuhan pelatihan kerja secara tepat, memberikan tanggung jawab yang sesuai kepada karyawan sehingga dapat melaksanakan pekerjaan yang lebih baik di masa mendatang dan sebagai dasar untuk menentukan kebijakan dalam promosi jabatan atau penentuan imbalan. Penilaian kinerja memacu pada suatu sistem formal dan terstruktur yang digunakan untuk mengukur, menilai dan mempengaruhi 
sifat-sifat yang berkaitan dengan pekerjaan.

Indikator untuk mengukur kinerja karyawan secara individu ada enam indikator, yaitu (Robbins, et,al, 2006): 1). "Kualitas; Kualitas kerja diukur dari persepsi karyawan terhadap kualitas pekerjaan yang dihasilkan serta kesempurnaan tugas terhadap keterampilan dan kemampuan karyawan. 2). Kuantitas; Merupakan jumlah yang dihasilkan dinyatakan dalam istilah seperti jumlah unit, jumlah siklus aktivitas yang diselesaikan. 3). Ketepatan waktu; Merupakan tingkat aktivitas diselesaikan pada awal waktu yang dinyatakan, dilihat dari sudut koordinasi dengan hasil output serta memaksimalkan waktu yang tersedia untuk aktivitas lain. 4). Efektivitas; Merupakan tingkat penggunaan sumber daya organisasi (tenaga, uang, teknologi, bahan baku) dimaksimalkan dengan maksud menaikkan hasil dari setiap unit dalam penggunaan sumber daya. 5). Kemandirian; Merupakan tingkat seorang karyawan yang nantinya akan dapat menjalankan fungsi kerjanya. Komitmen kerja merupakan suatu tingkat dimana karyawan mempunyai komitmen kerja dengan instansi dan tanggung jawab karyawan terhadap kantor".

\section{METODE PENELITIAN}

Penelitian ini untuk menjelaskan hubungan kausalitas variabel kompensasi dan disiplin kerja terhadap kinerja karyawan. Data yang digunakan dalam penelitian ini merupakan data primer melalui pengisian kuesioner kepada para karyawan PT. Pedagang Unggul Indonesia (X-Sell). Metode analisis yang digunakan adalah metode analisis regresi linear sederhana dan berganda. Penelitian ini dilakukan pada PT. Pedagang Unggul Indonesia (X-Sell), dan berlokasi di Wisma Daria, Jalan Iskandarsyah Raya
RT. 7/RW. 4, Melawai, Kebayoran Baru, Kota Jakarta Selatan, Jakarta 12160, Populasi berjumlah 30 orang/responden. Teknik pengambilan sampel dalam penelitian ini menggunakan teknik sampling jenuh (sensus), yaitu teknik pengumpulan sampel bila semua anggota populasi digunakan sebagai sampel.

\section{HASIL PENELITIAN DAN PEMBAHASAN}

\section{Uji Instrumen Data}

Berdasarkan uraian tersebut di atas, maka untuk dapat menentukan apakah variabel kompensasi dan disiplin kerja dapat dijadikan pengukur terhadap kinerja karyawan PT. Pedagang Unggul Indonesia (X-Sell). Namun sebelumnya data diolah terlebih dahulu dan dilakukan pengujian terhadap variabel yang digunakan yaitu kompensasi dan disiplin kerja dan kinerja karyawan untuk mengetahui apakah data tersebut akurat dan dapat dipercaya.

\section{Uji Validitas}

Pengujian validitas ini dilakukan untuk menguji apakah tiap butir pernyataan telah mewakili indikator yang akan diteliti, persyaratan minimum untuk dapat dikatakan valid adalah $r=0,30$. Jadi, apabila korelasi antara butir-butir item pernyataan dengan skor total kurang dari 0,30, maka butiran dalam instrumen tersebut dapat dikatakan tidak valid. Uji validitas dilakukan dengan melihat korelasi antara skor masing-masing item pernyataan dengan skor total.

\section{Uji Validitas Instrumen Variabel}

Dari perhitungan koefisien korelasi skor tiap butir pernyataan dari 30 responden tentang instrument kompensasi, dengan jumlah 10 pernyataan; instrumen disiplin kerja 8 pernyataan dan instrumen kinerja 
karyawan 10 pernyataan dan semua variabel menunjukkan bahwa $r$ hitung

\section{Uji Reliabilitas}

Pengujian reliabilitas ini dilakukan untuk menguji seberapa jauh hasil pengukuran yang dapat diandalkan secara konsisten. Pada tabel hasil pengujian lebih besar dari $\mathrm{r}$ kritis $=0.3$, hasilnya adalah valid.

Tabel 1: Hasil Uji Reliabilitas Variabel

\begin{tabular}{lcc}
\hline \multicolumn{1}{c}{ Variabel } & Cronbach's Alpha & Keterangan \\
\hline Kompensasi & 0.850 & Reliabel \\
Disiplin Kerja & 0.858 & Reliabel \\
Kinerja Karyawan & 0.840 & Reliabel \\
\hline
\end{tabular}

Sumber: Hasil pengolahan data, 2020

Berdasarkan Tabel 1, dapat disimpulkan bahwa nilai Cronbach's Alpha positif dimana lebih besar dari 0,6 yang merupakan batas minimal koefisien reliabilitas berikut, diketahui bahwa semua variabel mempunyai alpha di atas 0,6 yang berarti bahwa semua variabel dalam penelitian ini dapat diandalkan.

\section{Analisis Hasil Penelitian}

Tabel 2: Pengaruh Kompensasi Terhadap Kinerja Karyawan PT. Pedagang Unggul Indonesia (X-Sell)

\begin{tabular}{lccccc}
\hline \multirow{2}{*}{ Variabel } & R Square & Konstanta & $\begin{array}{c}\text { Koef. } \\
\text { Regresi }\end{array}$ & Sig. & $\boldsymbol{\alpha}$ \\
\cline { 2 - 6 } & 0.713 & 7.981 & 0.854 & 0.000 & 0.05 \\
\hline Kompensasi & & & & \\
\hline Pengujian Signifikansi & & & & & \\
\hline t hitung $>$ t tabel $=8.343>2.048$ &
\end{tabular}

Keterangan: Variabel Kinerja Karyawan

Sumber: data diolah 2020

Berdasarkan Tabel 2, nilai koefisien determinasi $\left(\mathrm{R}^{2}\right)$ sebesar 0.713, artinya variabel kompensasi memberikan kontribusi sebesar 71,3\% terhadap kinerja karyawan PT. Pedagang Unggul Indonesia (X-Sell), sedangkan sisanya sebesar $28,7 \%$ disumbangkan faktor lain. reliabilitas dapat dianggap baik. Dengan demikian, dikatakan bahwa pernyataan di atas reliabel. 
Unggul Indonesia (X-Sell). Koefisien kompensasi sebesar 0,854, artinya jika ada peningkatan kompensasi, maka kinerja karyawan PT. Pedagang Unggul Indonesia (X-Sell) akan meningkat atau sebaliknya.

Untuk menguji hubungan secara parsial variabel kompensasi terhadap kinerja karyawan PT. Pedagang Unggul Indonesia (X-Sell) signifikan atau tidak, dilakukan pengujian $t$ hitung dibandingkan dengan $t$ tabel dengan tingkat $\alpha=0,05$, hasilnya adalah $\mathrm{t}$ tabel $=2,048$ yang dilihat dari tabel distribusi $\mathrm{t}$ (derajat kebebasan $=n-2 ;(30-2=28)$, dengan uji dua pihak). Berdasarkan perhitungan tersebut dapat dinyatakan bahwa nilai t hitung $=8,343$ lebih besar dari $\mathrm{t}$ tabel $=2,048$, maka dapat diartikan terdapat pengaruh yang positif dan signifikan kompensasi terhadap kinerja karyawan PT. Pedagang Unggul Indonesia (X-Sell).

Tabel 3: Pengaruh Disiplin Kerja Terhadap Kinerja Karyawan PT. Pedagang Unggul Indonesia (X-Sell)

\begin{tabular}{lccccc}
\hline \multirow{2}{*}{ Variabel } & R Square & Konstanta & $\begin{array}{c}\text { Koef. } \\
\text { Regresi }\end{array}$ & Sig. & $\boldsymbol{\alpha}$ \\
\cline { 2 - 6 } & 0.651 & 9.700 & 0.969 & 0.000 & 0.05 \\
\hline Disiplin Kerja & & & & \\
\hline Pengujian Signifikansi & & & & \\
\hline t hitung $>$ t tabel $=7.220>2.048$ &
\end{tabular}

Keterangan: Variabel Kinerja Karyawan

Sumber: data diolah 2020

Berdasarkan Tabel 3, nilai koefisien determinasi $\left(\mathrm{R}^{2}\right)$ sebesar 0.651, artinya disipln kerja memberikan konstribusi sebesar $65,1 \%$ terhadap kinerja karyawan PT. Pedagang Unggul Indonesia (X-Sell), sedangkan sisanya sebesar $34,9 \%$ disumbangkan faktor lain.

Persamaan Regresi $\mathrm{Y}=9,700+0,969$ $\left(\mathrm{X}_{2}\right)$

Disiplin kerja berpengaruh positif dan signifikan pada tingkat nyata 95\% terhadap kinerja karyawan PT. Pedagang Unggul Indonesia (X-Sell). Koefisien disiplin kerja sebesar 0,969, artinya jika ada peningkatan disiplin kerja, maka kinerja karyawan PT. Pedagang Unggul
Indonesia (X-Sell) akan meningkat atau sebaliknya.

Untuk menguji hubungan secara parsial variabel disiplin kerja terhadap kinerja karyawan PT. Pedagang Unggul Indonesia (X-Sell) signifikan atau tidak, dilakukan pengujian $\mathrm{t}$ hitung dibandingkan dengan $t$ tabel dengan tingkat $\alpha=0,05$, hasilnya adalah $t$ tabel $=2,048$ yang dilihat dari tabel distribusi $\mathrm{t}$ (derajat kebebasan $=n-2 ;(30-2=28)$, dengan uji dua pihak). Berdasarkan perhitungan tersebut di atas dapat dinyatakan bahwa nilai t hitung $=7,220$ lebih besar dari t tabel $=2,048$, maka dapat diartikan terdapat pengaruh yang positif dan signifikan variabel disiplin kerja terhadap kinerja karyawan PT. Pedagang Unggul Indonesia (X-Sell).

Tabel 4: Pengaruh Kompensasi dan Disiplin Kerja Terhadap Kinerja Karyawan PT. Pedagang Unggul Indonesia (X-Sell)

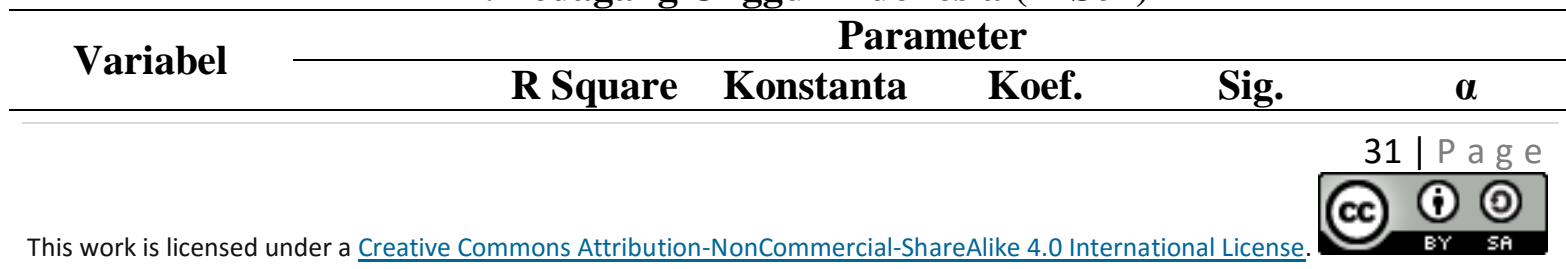




\begin{tabular}{|c|c|c|c|c|c|}
\hline & \multicolumn{5}{|c|}{ Regresi } \\
\hline $\begin{array}{l}\text { Kompensasi } \\
\text { Disiplin Kerja }\end{array}$ & 0.748 & 5.889 & $\begin{array}{l}0.570 \\
0.406\end{array}$ & 0.003 & 0.05 \\
\hline
\end{tabular}

Pengujian Signifikansi

F hitung $>\mathrm{F}$ tabel $=40.117>3.354$

Keterangan: Variabel Kinerja Karyawan

Sumber: data diolah 2020

Pada Tabel 4, Nilai $F$ hitung sebesar 40,117 jika dibadingkan dengan $F$ tabel sebesar 3,354 yang didapat dari $(\mathrm{DK}=\mathrm{n}-\mathrm{k}-1 ;=30-2-1=27)$, maka $\mathrm{F}$ hitung lebih besar dari $\mathrm{F}$ tabel $(40,117>3,354)$, artinya secara bersamasama kompensasi dan disiplin kerja berpengaruh positif dan signifikan pada tingkat nyata $95 \%$ terhadap kinerja karyawan PT. Pedagang Unggul Indonesia (X-Sell), atau dengan menggunakan $\mathrm{F}$ signifikan yaitu sebesar 0,003 lebih kecil dari tingkat kepercayaan 0,05 .

Nilai koefisien determinasi $\left(\mathrm{R}^{2}\right)$ sebesar 0.748, artinya kompensasi dan disiplin kerja memberikan kontribusi sebesar 74,8\% kepada kinerja karyawan PT. Pedagang Unggul Indonesia (X-Sell), sedangkan sisanya sebesar $25,2 \%$ disumbangkan faktor lain yang tidak dibahas dalam penelitian ini.

Persamaan Regresi $\mathrm{Y}=5,889+0,570$ $\left(\mathrm{X}_{1}\right)+0,406\left(\mathrm{X}_{2}\right)$

Kompensasi dan disiplin kerja berpengaruh positif dan signifikan terhadap kinerja karyawan PT. Pedagang Unggul Indonesia (X-Sell), pada tingkat nyata $95 \%$. Koefisien kompensasi sebesar 0,570 artinya jika ada peningkatan kompensasi, maka kinerja karyawan PT. Pedagang Unggul Indonesia (X-Sell) akan meningkat atau sebaliknya dengan asumsi disiplin kerja tidak berubah. Koefisien disiplin kerja sebesar 0,406, artinya jika ada peningkatan disiplin kerja, maka kinerja karyawan PT. Pedagang Unggul Indonesia (X-Sell) akan meningkat atau sebaliknya, dengan asumsi kompensasi tidak berubah.

\section{Pembahasan}

\section{Pengaruh Kompensasi Terhadap Kinerja Karyawan}

Hasil penelitian menunjukan bahwa kompensasi mendukung peningkatan PT Pedagang Unggul (X-Sell). Hal ini menunjukkan semakin baik kompensasi yang diberikan oleh perusahaan akan dapat meningkatkan kinerja karyawan. Gaji yang diterima karyawan setiap bulan sesuai waktu dan dapat memenuhi kebutuhan keluarga. Hasil penelitian ini sejalan dengan penelitian yang dilakukan oleh Purnama dan Kempa, (2016), dan Isvandiari (2017) yang menyatakan bahwa kompensasi berpengaruh signifikan terhadap kinerja karyawan.

\section{Pengaruh Disiplin Kerja Terhadap Kinerja Karyawan}

Hasil penelitian menyatakan bahwa disiplin kerja mendukung peningkatan kinerja karyawan PT Pedagang Unggul (X-Sell). Hal ini disebabkan bahwa disiplin kerja yang ditetapkan oleh perusahaan dilaksanan sesuai dengan ketentuan ini dapat terlihat karyawan datang lebih awal ketempat kerja dan pekerjaan dikerjakan sesuai dengan yang sudah direncanakan. Hasil penelitian ini sejalan dengan hasil penelitian yang dilakukan Armansyah, et, al (2018) yang menyatakan bahwa disiplin kerja berpengaruh signifikan terhadap kinerja karyawan. 


\section{Pengaruh Kompensasi dan Disiplin kerja Terhadap Kinerja Karyawan}

Berdasarkan hasil analisis diketahui bahwa kompensasi dan disiplin kerja mendukung peningkatan kinerja karyawan PT Pedagang Unggul (X-Sell). Hasil penelitian ini sama dengan hasil penelitian yang dilakukan Purnama dan Kempa, (2016), Isvandiari (2017), dan Armansyah, et, al (2018) yang menyatakan bahwa yaitu menganalisis pengaruh kompensasi dan disiplin kerja berpengaruh terhadap kinerja karyawan.

\section{KESIMPULAN DAN SARAN}

\section{Kesimpulan}

Dari hasil analisis dan pembahasan yang tertuang pada Bab IV, dapat diambil kesimpulan bahwa: 1). Kompensasi berpengaruh positif dan signifikan terhadap kinerja karyawan PT. Pedagang Unggul Indonesia (X-Sell). 2). Disiplin kerja berpengaruh positif dan signifikan terhadap kinerja karyawan PT. Pedagang Unggul Indonesia (X-Sell). 3). Kompensasi dan disiplin kerja berpengaruh positif dan signifikan terhadap kinerja karyawan PT. Pedagang Unggul Indonesia (X-Sell).

\section{Saran}

Berdasarkan analisis dan pembahasan pengujian secara empiris suatu kesimpulan yang dikemukakan di atas, Peneliti pada sub bagian ini mencoba memberikan rekomendasi atau saran yang mungkin dapat ditindaklanjuti oleh PT. Pedagang Unggul Indonesia (X-Sell) sebagai berikut: 1). Kompensasi yang diberikan oleh perusahaan kepada karyawan sudah sesuai dengan ketentuan yang berlaku, sehingga semua karyawan memiliki tanggung jawab dan loyalitas yang cukup baik terhadap perusahaan, hal ini terlihat dari hasil kinerja yang dilaksanakan sudah dapat memenuhi standar yang ditetapkan. 2). Disiplin kerja karyawan terlihat sudah baik, karyawan hadir sesuai dengan waktu yang ditetapkan, tanggung jawab terhadap pekerjaan dapat dipercaya, ketaatan mengikuti aturan dan patuh terhadap perintah pimpinan, ini semua dilaksanakan dengan baik. 3). Bagi peneliti selanjutnya disarankan untuk menambah variabel-variabel lain yang lebih beragam dalam membahas yang berkaitan dengan kinerja karyawan dalam perusahaan yang bergerak dibidang jasa pemasaran atau direct selling.

\section{DAFTAR PUSTAKA}

Armansyah, Andi,. Azis, Idri dan Rossanty, Niluh Putu Evvy. 2018. "Pengaruh Kompensasi dan Disiplin Kerja Terhadap Kinerja Pegawai Kantor BPJS Kesehatan Cabang Palu". Jurnal Ilmu Manajemen Universitas Tadulako Vol. 4, No. 3, September 2018.

Dessler, Gary .2011. Manajemen Sumber Daya Manusia. Diterjemahkan oleh: Benyamin Molan. Jakarta: Indeks Kelompok Gramedia.

Gomes, Faustino Cardoso. 2003. Manajemen Sumber Daya Manusia. Yogyakarta: Andi Offset

Hasibuan, Malayu S.P. 2013. Manajemen Sumber Daya Manusia. Edisi Revisi. Jakarta: Bumi Aksara.

Isvandiari, Any. 2017. "Pengaruh Kompensasi dan Disiplin Kerja Terhadap Kinerja Karyawan Bagian Produksi PG. Meritjan Kediri”. Jurnal JIBEKA, Volume. 11, No. 1, Agustus Tahun 2017.

Kasmir. 2016. Manajemen Sumber Daya Manusia. Cetakan Ke 5. Jakarta: PT. Raja Grafindo Persada.

Luthans, Fred. 2012. "Perilaku Organisasi”. Yogyakarta: Andi. 
Mangkunegara, A.P. 2017. Manajemen Sumber Daya Manusia Perusahaan. Cetakan 14 Bandung: Remaja Rosdakarya.

Moekijat. 2011. Latihan dan Pengembangan Sumber Daya Manusia. Bandung: Bandar Maju.

Moenir, H.A.S. 2014. Manajemen Pelayanan Umum di Indonesia. Jakarta: Bumi Aksara.

Nurlaila. 2010. Manajemen Sumber Daya Manusia I. Ternate: LepKhair

Purnama, Catherine dan Kempa, Sesilya. 2016. "Pengaruh Kompensasi dan Disiplin Kerja Terhadap Kinerja Karyawan CV Cahaya Citra Surya Indonesia". Jurnal AGORA Vol. 4, No. 2, Tahun 2016.

Rivai, Veitzhal. 2010. Manajemen Sumber Daya Manusia Untuk Perusahaan. Jakarta: PT. Ganudra Pustaka Utama.
Robbins, P. Stephen \& Judge, Timothy A. 2017. Organizational Behaviour. Edisi13. Jilid 1. Jakarta: Salemba Empat.

Saydam, Gouzaly. 2011. Manajemen Sumber Daya Manusia. Jakarta: Gunung Agung.

Sedarmayanti. 2016. Manajemen Sumber Daya Manusia. Bandung: PT. Refika Aditama.

Sofyandi, Herman. 2008. Manajemen Sumber Daya Manusia. Yogyakarta: Graha Ilmu.

Sugiyono. 2016. Statikstika Untuk Penelitian. Bandung: Alfabeta.

Sutrisno, Edy. 2011. Manajemen Sumber Daya Manusia. Jakarta: Kencana.

Umam, Khaerul. 2010. Perilaku Organisasi. Bandung: Pustaka Setia. 